
\title{
28 Research Square \\ Feasibility Studies on Treatment of Household Greywater Using Phytoremediation Plants
}

Neetha Delphin Mary Kulandaiswamy ( $\sim$ neethak81@gmail.com )

Salem College of Engineering and Technology https://orcid.org/0000-0003-2341-8760

Muralimohan Nithyanandam

KSR College of Engineering

\section{Research Article}

Keywords: Greywater, Vertical flow Construction wetland, Phytoremediation, Cyperus rotundus, Canna indica, Typha angustifolia, Cyperus pangorei, Phragmites australis

Posted Date: December 21st, 2021

DOI: https://doi.org/10.21203/rs.3.rs-1139760/v1

License: (1) This work is licensed under a Creative Commons Attribution 4.0 International License. Read Full License 


\section{Abstract}

Recycling and reusing of wastewater acquired high priority among the research community to meet the ever-increasing demand for groundwater, and to tackle water scarcity in every country. In this scenario, a grey water treatment system is developed with a vertical flow wetland construction tank (VFWCT)with sand, gravel and silex as media combined with phytoremediation technology using plants like Cyperus rotundus, Canna indica, Typha angustifolia, Cyperus pangorei, and Phragmites australis. The assessment parameters like color, odor, temperature, $\mathrm{pH}$, electrical conductivity, free residual chlorine, Total Dissolved Solids (TDS), chloride, Sulphate, Total Suspended Solids (TSS),oil \& grease, Sulphide,Biochemical Oxygen Demand (BOD), Chemical Oxygen Demand (COD), Nitrate Nitrogen, E.coli and Salmonella are used to substantiate the performance of proposed greywater treatment system. Simulation outcomes showed that most of the guideline values of the effluent are notably lower compared to the influent. The experimentation also focused on finding the best plant as Typha angustifolia for greywater treatment in the VFWCT. The plant's rapid growth and the removal efficiency parameters of the plant with regard to the contaminants present in the greywater was highly notable. The removal efficiency was $56.56 \%$ and $50.25 \%$ for BOD5 and COD, the solids content TSS and TDS was $68 \%$ and $64.4 \%$. The salt $\mathrm{Cl}^{-}$and $\mathrm{Na}^{+}$ removal efficiencies are $63.4 \%$ and $81.39 \%$ respectively. Majority of the parameters like pH value, Electrical conductivity, odor and TDS are higher than the groundwater aquifers, but falls within the world health organization safety limits.

\section{Introduction}

India is facing a water calamity and by 2025 it is roughly calculated that India's inhabitants will be distressed from severe water shortage (Hernández Leal et al.2010) With increased population widening and evolution, there is a need to seriously look at alternative approaches to ensure water availability. These alternative resources incorporate rainwater reservoirs and bulk of water from laundry machine, wash basin, kitchen sink and bath rooms, used in household that emerges as grey water with some minerals, organic waste materials dissolved and suspended in it. (Li et al.2010, Oteng-Peprah et al.2020) In recent years not only the warning of unethical greywater management has been recognized but also there is an increasing worldwide recognition that greywater reuse, if duly done, has a prominent aptitude as alternative water source for grounds such as irrigation, gardening, toilet flushing, car washing and laundry wash (Deng et al.2020)

The greywater treatment systems are positioned based on close- packed aerobic systems like bio-filters, bio-reactors, and bio-rotors which require more maintenance cost, large space to construct and consumes more electrical or mechanical energy for greywater treatment (Abdel hay and Abunaser 2020, Pradhan et al.2020, Raphael et al.2020). To underscore these problems, the scope of this research study is made to treat the greywater at household level of about 750-1000 liter/day by using phytoremediation technology, where the usage of naturally or genetically engineered plants are planted to absorb, filter and remove contaminants from soil and water in a vertical flow constructed wetland (VFCW) tank (Abed et al.2019, Manzoni et al.2011, Canales-Pastrana and Paredes.2013) Wastewater treatment using a 
phytoremediation method offers several advantages, such as cost-effective approach, minimum energy requirement, minimal environmental disturbance, conservation of soil biological activity (Neharika Chandekar and Buddharatna J. Godboley.2015). The greywater is dosed onto the planted filer bed surface vertically using a mechanical dosing system and the drain is collected at the bottom of the wetland tank after the retention time. The final treated water can be used for organic gardening. The objective of this exploration work is to reduce water scarcity, increase ground-water table, improve the environmental resources with 3R concepts, make greywater treatment easier, less expensive and reduce fouling.

\section{Materials And Methods 2.1 Materials}

The greywater treatment plant was installed in a house of 3 families with 10 individuals at Salem, Tamilnadu. The generation of greywater per day is 750-1000 liters/ day which were collected in a 1000 liters Collection tank and transferred to a 1000 liters retention tank using $1 \mathrm{Hp}$ sewage motor. The design and size $(\mathrm{L} 51 \mathrm{~cm} * B 21 \mathrm{~cm} * \mathrm{H} 80 \mathrm{~cm})$ of 5 VFCW tanks were done according to the "Manual on constructed wetland as an alternative technology for sewage management in India" (Department of biotechnology, Ministry of science \& technology, Central pollution control board, Ministry of environment, forest\& climate change, Government of India).(Beauchamp and Adamowski.2012) The filter media was filled in the vertical tanks in descending order accordingly as coarse sand of $15 \mathrm{~cm}$, coarse silex of $15 \mathrm{~cm}$, gravel $20 \mathrm{~mm}$ of $20 \mathrm{~cm}$, gravel $40 \mathrm{~mm}$ of $20 \mathrm{~cm}$, and free board of $10 \mathrm{~cm}$. In this plank, Canna indica, Phragmites australis, Typha angustifolia, Cyperus pangorei and Cyperus rotundus are opted for plantation in the vertical tanks. These plants were selected as the phytoremediation agents in this study because of their rapid growth rate and tolerance to various environmental conditions. The selected plants are represented in figure 1.

The greywater was made to flow vertically and continuously through the planted filter media. The selected plants delivered suitable conditions for transporting oxygen to root zone, microbial attachment and better growth. (Oren Shelef et al.2013). Hence, the suspended solids and the organic matter were withdrawn by microbial degradation and filtration in anoxic, aerobic and anaerobic conditions.

\subsection{Method}

In this methodology, greywater was collected from bathroom, cooking area, and launderette for treatment. The bathroom greywater consists of minimally contaminated greywater source within a household. The bathroom greywater consists of toothpaste, soap, shampoo, hair, shaving waste, and other body care products (Samayamanthula et al.2019, Mohamed et al.2018). The kitchen greywater included maximum amount of fat, oil, and food residues. The dishwasher greywater had highly soluble salt concentrations, and suspended solids (Dal Ferro et al.2020). The Laundry greywater consists of higher concentration of chemical from bleaches, lather, solvents, suspended solids, colorants and non-biodegradable fiber from clothing (Noutsopoulos et al. 2018, Spangler et al.2019), were collected in a 1000-liter collection tank, after stirring it was transferred to 1000 liters retention tank using a $1 \mathrm{HP}$ sewage motor. 
A single vertical unit was filled with raw greywater until the free board of the tank at a retention time of 12 hrs. The important water parameters for the vertical raw influent greywater $\left(\mathrm{V}_{\mathrm{RI}}\right)$ like color, Odor, Temperature were checked insitu and parameters like Electrical conductivity(Ec),Total suspended solids(TSS), Total Dissolved solids(TDS), Chloride as $\mathrm{Cl}^{-}$, Sulphate as $\mathrm{SO}_{4}{ }^{-}$, Free residual chlorine as $\mathrm{Cl}_{2}$, oil \& grease, Sulphide as S, Nitrate Nitrogen, Bio-Chemical oxygen Demand(BOD), Chemical oxygen Demand (COD), Salmonella, and E.coli were tested in laboratory (Table 1). The greywater filled single vertical unit was drained thoroughly. The water was collected in a container and measured after Evaporation. 
Table 1

Testing Methods of Each Parameter

\begin{tabular}{|c|c|c|c|}
\hline $\begin{array}{l}\text { S. } \\
\text { No }\end{array}$ & $\begin{array}{l}\text { Name of the } \\
\text { Parameters }\end{array}$ & BIS code & Test Method \\
\hline 1 & Color & IS 3025 PART 4 & $\begin{array}{l}\text { Platinum Cobalt (Visual Comparison } \\
\text { Method) }\end{array}$ \\
\hline 2 & Odor & IS 3025 PART 5 & Sensory Attributes \\
\hline 3 & Temperature & IS 3025 PART 9 & Thermometer method \\
\hline 4 & $\mathrm{pH}$ & IS 3025 PART 11 & pH Electrode Method \\
\hline 5 & $\begin{array}{l}\text { Electrical } \\
\text { Conductivity }\end{array}$ & IS 3025 PART 14 & $\begin{array}{l}\text { Wheat stone Bridge - Conductance Cell } \\
\text { Method }\end{array}$ \\
\hline 6 & $\begin{array}{l}\text { Total Dissolved } \\
\text { Solids }\end{array}$ & IS 3025 PART 16 & Gravimetric Method \\
\hline 7 & $\begin{array}{l}\text { Total Suspended } \\
\text { Solids }\end{array}$ & IS 3025 PART 17 & Gravimetric Method \\
\hline 8 & Chloride & IS 3025 PART 32 & Titration Method \\
\hline 9 & Sulphate & IS 3025 PART 24 & $\begin{array}{l}\text { Precipitation - UV Spectrophotometric } \\
\text { Method }\end{array}$ \\
\hline 10 & $\begin{array}{l}\text { Free Residual } \\
\text { Chlorine }\end{array}$ & IS 3025 PART 26 & Titration Method \\
\hline 11 & Sulphide & IS 3025 PART 29 & Titration Method \\
\hline 12 & Oil \& Grease & GLCS/SOP/W/025 & Gravimetric Method \\
\hline 13 & Nitrate Nitrogen & IS 3025 PART 34 & Devarda's Alloy Reduction Method \\
\hline 14 & BOD & IS 3025 PART 44 & Titration Method \\
\hline 15 & COD & IS 3025 PART 58 & Titration Method \\
\hline 16 & E coli & $\begin{array}{l}\text { APHA 23rd edition chapter- } \\
9221\end{array}$ & Membrane Filtration Method \\
\hline 17 & Salmonella & $\begin{array}{l}\text { APHA 23rd edition chapter- } \\
9260 \mathrm{~B}\end{array}$ & Detection Method \\
\hline
\end{tabular}

The five phytoremediation plant samplings of 3 no's each were washed with water to remove foreign contaminants, soaked in aloe vera pulp solution to add micro nutrients for better growth were planted in individual vertical tanks. The grey water was watered once in $24 \mathrm{hrs}$. for the experimental period of 90 days.The 17 observation parameters were recorded at intervals of $30,45,60,75$ and 90 days at a retention time of $12 \mathrm{hrs}$. at Insitu and at laboratory. On the 90th day the individual vertical tanks were drained thoroughly and separately. The drained water was collected in containers and measured. The 
amount of measured water is the treated greywater after Evapotranspiration. The growth of plants on the 90th day of the experiment are shown in figure 2.

\section{Results And Discussions}

The treated water, drained from the five vertical tanks were collected and tested for assessing the efficacy of treatment beds and plants in grey water remediation. The quality of grey water both before and after treatment were analyzed and the results were compared with the value, obtained prior to the treatment. The observations are as follows,

\subsection{Effect of Phytoremediation on Temperature, Color and Odor}

Temperature plays a vital role in the chemical and biological activities of water bodies. It always gets influenced by external environment hence there was a fall and rise in temperature in all the 5 phytoremediation VFWC tanks. The temperature was recorded as 29.1 as the lowest and 29.5 as the highest. The temperature of untreated and treated greywater did not change substantially throughout the duration of the experimental run (Rajnikant Prasad et al.2021). Phytoremediation treatment of grey water using Canna indica, Phragmites australis, Typha angustifolia, Cyperus pangorei, and Cyperus rotundus showed reasonable decrease in color and odor. The color of the influent water was blackish, in gradual duration of the experiment there was a significant reduction in blackish color to transparency. Unpleasant odor occurred at the preliminary phase of the treatment; the methodology is efficient enough to remove the odor due to Sulphide in greywater to odorless recycled water in due course of 90 days.

\subsection{Effect of Phytoremediation on pH}

$\mathrm{pH}$ is a figure expressing the acidity or alkalinity of a solution on a logarithmic scale on which 7 is neutral. Lower values are acidic and higher values are more alkaline. The $\mathrm{pH}$ of greywater before treatment was 7.9. The percentage removal efficiencies of Canna indica, Phragmites australis, Typha angustifolia, Cyperus pangorei, and Cyperus rotundus at the end of 90th day were 83.3,82.2,83.5,81,83.5. The $\mathrm{pH}$ change was caused by an imbalance in uptake by roots of cations and anions, $\mathrm{CO} 2$ respiration, excretion of organic acids from roots and microbial activity. (Jianjun Chen.2003).

\subsection{Effect of Phytoremediation on Electrical Conductivity}

The potential of the greywater was a compute of the salinity of all diffused ions present. The Ec factor affects the bioavailability of metals to the plants. When salts, acids or bases gets dissolved in water, they can exist as ions and as electrolytes. The conductivity of the medium decreases as the cationic metal of rhizosphere decreases in the unsaturated medium. The conductivity value obtained from the five plants investigated in this study were well below the value that it could not lead to adverse effects when used for irrigation (Bakare et al.2017). The initial reading of Ec was $2180 \mu \mathrm{S} / \mathrm{cm}$. On the final accounting of the experiment the removal efficiency (\%) was $90.0,89.6,89.4,89.8,90.0$ by Canna indica, Phragmites australis, Typha angustifolia, Cyperus pangorei, and Cyperus rotundus. 


\subsection{Effect of Phytoremediation on TSS}

TSS is an important factor in regulating the integrity of water. Turbidity of the water increases with the increase in quantity of suspended solids. The suspended solids were made up of inorganic materials, bacteria and algae. The scaling down in the average reading for TSS was fundamentally due to the plants' root systems. The absorption of root capacity increases with the growth of the plant and hence more suspended solids can be filtered by sedimentation. During a lower water flow rate, there was an increase in suspended solids and so there was an increase in solids filtration by plant tissues (Nur Izzah Hamna Abdul Aziz et al.2020, Raju et al. 2010). The initial TSS of raw greywater reading was $150 \mathrm{mg} / \mathrm{l}$. On the completion of the experiment the observations showed a percentile reduction of TSS as 65.6,65.0,68.0,64.0,67.3 by Canna indica, Phragmites australis, Typha angustifolia, Cyperus pangorei, and Cyperus rotundus.

\subsection{Effect of phytoremediation on TDS}

TDS is a computation of inert salts, organic matter and other dissolved materials in water. The noxious of TDS was affected by escalation in salinity, swaps in the ionic composition of the water, and toxicity of unique ions (Sheena and Harsha.2016, Adonadaga et al.2020).Removal efficiency was enhanced up to 84.4 by Typha angustifolia the highest, followed by 83.9 by Cyperus rotundus, 82.6 by Cyperus pangorei, 82.3 by Canna indica and 81.8 by phragmites australis the lowest. As result of phytoremediation, the palatability was restored to a great extent.

\subsection{Effect of Phytoremediation on BOD and COD}

BOD and COD are the most vital factor in water pollution control since it indicates the actual level of biodegradable pollutants and the amount of oxygen required to oxidize the domestic and industrial pollutants in the greywater (Nur Izzah Hamna Abdul Aziz et al.2020). The aerobic and anaerobic bacteria carry out active role in the reduction of COD and BOD of wastewater. The dissolved oxygen in water is increased due to photosynthesis process and hence the aerobic condition in wastewater is created to induce the aerobic bacterial activity to breakdown the BOD and COD contents. The reduction in BOD \& COD by phytoremediation specifies that the greywater will have a lesser consequence when used for secondary uses. (Adonadaga et al.2020, Chavan and Dhulap.2012). The removal efficiency of BOD in percentage by phytoremediation is observed in Canna indica as 56.6 followed by Typha angustifolia with $54.7,53.5$ by phragmites australis, 51.5 by Cyperus pangorei and the lowest as 49.2 by Cyperus rotundus, where the initial BOD value was noted as $126 \mathrm{mg} / \mathrm{l}$.

The COD removal efficiency by the plant-based technology on greywater treatment was observed as $50.25 \%$ the highest by Canna indica and Cyperus rotundus, $49 \%$ Typha angustifolia, $48.5 \%$ by phragmites australis, $48.25 \%$ by Cyperus pangorei, where the initial COD value was $400 \mathrm{mg} / \mathrm{l}$.

\subsection{Effect of Phytoremediation on Chlorides and Sulphates}


Plants that can survive in saline environment are called halophytes. These plants pile up and reserve the salt ions in their vacuoles to maintain a proper osmotic slope to remain alive in the saline ecosystem. lons such as $\mathrm{Na}^{+}$and $\mathrm{Cl}^{-}$gets accumulated in recirculating greywater and reach levels of damaging crops. Such hyperaccumulating plants with $\mathrm{Na}+$ and cl- can undergo Phyto- desalinization using wetland construction. Typha angustifolia which can survive in a variety of conditions, was observed to behave well to accumulate $\mathrm{Na}^{+}$and $\mathrm{Cl}^{-}$from greywater in a wetland construction tank (Eric et al.2014). The $\mathrm{Cl}^{-}$ removal efficiencies of the plant recorded $63.4 \%$ followed by $62.7 \%$ by Cyperus rotundus, $61.9 \%$ by Canna indica, $61.4 \%$ by phragmites australis and finally $60.2 \%$ by Cyperus pangorei with phytoremediation.

The sulphate removal efficiencies of the phytoremediation process shown by the selected plants were $78.6 \%$ by Canna indica, 79.6 by phragmites australis, $81.39 \%$ by Typha angustifolia, $78.1 \%$ by Cyperus pangorei, $80 \%$ by Cyperus rotundus. Similar to $\mathrm{Cl}^{-}$ion reduction Typha angustifolia showed higher $\mathrm{Na}^{+}$ ion reduction and pangorei showed the lowest $\mathrm{Na}+$ reduction.

\subsection{Effect of Phytoremediation on E. coli and Salmonella}

Microbial communities have an essential role in the organic and inorganic pollutant removal process and plant growth promotion. Some functional micro-organisms in roots helps to remove pollutants from greywater, meanwhile some microbe's aids in plant growth. The effectiveness of E. coli and salmonella removal depends on criteria like selection of plants, non-invasive species, the ability of the plant to survive in a hydroponic environment with ample roots and aerated tissue (Munazzam Jawad Shahid et al.2020). Phytoremediation has the potential to abolish organic and inorganic adulterant but its capability to detach or disengage pathogens considered to be essential to human health is still being interrogated. The reduction of E. coli and salmonella was least by the plant treatment method. The lesser removal of E. coli and salmonella was due to the e ineffective treatment of plants in filtering the bacteria on its roots (Ni Nyoman Nepi Marleni et al.2020). The quantity of E. coli was $>1600 \mathrm{MPN} / 100 \mathrm{ml}$ and Salmonella was $18 \mathrm{MPN} / 1$ lit initially in the raw greywater. The observation for all the five plants was noted but there was no significant reduction until the end of the experiment by phytoremediation method.

\subsection{Effect of Phytoremediation on Free Residual Chlorine, Sulphide, Oil \& Grease \& Nitrate -Nitrogen}

Free chlorine or Free residual chlorine is the amount of chlorine present in the greywater to inactivate the pathogens that causes water borne diseases. The amount of free chlorine in the initial and throughout the duration of the experiment was Below detection level (BDL)/ Minimum detection level (MDL) mg/l. The detection level was BDL(DL:1) $\mathrm{mg} / \mathrm{l}$.

Sulphide as gas is formed in wastewater collection tank that create a septic condition. Sulphide combines with hydrogen forming hydrogen Sulphide $\left(\mathrm{H}_{2} \mathrm{~S}\right)$ producing "rotten egg" odor associated with wastewater. The measure of Sulphide in the raw greywater and in the finally treated water was in the detection level of $B D L(D L: 1) \mathrm{mg} / \mathrm{l}$. 
Greywater contain notable amount of fat in the form of oil and grease (O\&G) emanating mainly from kitchen sinks and dishwashers (e.g. cooking grease, vegetable oil, food grease etc.). O\&G intensification can also be perceived in bathroom and laundry greywater, with concentrations range between 35 and $80 \mathrm{mg} / \mathrm{l}$ and $5-45 \mathrm{mg} / \mathrm{l}$. Oil \& grease from kitchen greywater depends on the cooking and disposal methods of the households to a great extent. From the start to the end of the experimentation the amount of $O \& G$ was observed as BDL(DL:5) $\mathrm{mg} / \mathrm{l}$.

Nitrate-Nitrogen in greywater is derived from ammonia and ammonia-containing soaps, detergents, bleaches and stain removers as well as from polypeptides in meats, greens, protein shampoos. Levels of nitrogen in greywater are relatively low. The main source of nitrogen is kitchen wastewater in household greywater and the lowest nitrogen levels are from bathroom and laundry greywater. The initial and the final value of nitrate-Nitrogen is BDL(DL:2) mg/l. (Morel and Diener.2006, Nandhagopal Boopathi and Rajeshkumar Kadarkarai.2021, Mónica Eljaiek-Urzola et al.2019)

\subsection{Effect of Evapotranspiration (ET) on Greywater}

Evaporation is a type of vaporization that occurs on the surface of a liquid as it changes into gas and transpiration is the exhalation of water through the stomata present in leaves. The water loss by the combination of both the processes is called Evapotranspiration. Factors that affect the rate of ET include the amount of solar radiation, atmospheric vapor pressure, wind, temperature, soil moisture. Estimation of ET rate is very much important in planning irrigation. The initial grey water effluent after evaporation through the filter media measured at the retention time of $12 \mathrm{hrs}$. was 78 liters for all the five plants. At the count of 90th day, the percentage of greywater lost through ET by Canna indica was 11.25, the highest as the leaves of the plant has broader surface area which is eminent for more transpiration. The ET percentage for Cyperus rotundus, Typha angustifolia and Phragmites australis are8.5,10.11 and 7.9 respectively. These plants have a greater number of ribbon- shaped longer leaves and has a fibrous root system. Cyperus pangorei records the lowest ET percentile of 6.37 as the plant has fleshy, cylindrical leaves of less numbers. (Crundwell .1986, Michael L. Goulden et al.2007, Cristina Negri and Ray R. Hinchman .1996). The ET loss of greywater was calculated using the formula

\begin{tabular}{cc} 
Loss of Greywater through ET $(\%)=$ & (Initial-Final) \\
\hdashline & Initial
\end{tabular}

\section{Disinfection Process}

Disinfection is a process that destroys all forms of microbial life by physical or chemical methods. It is a proven method of ridding water borne diseases. Disinfectants, which work by destroying the cell wall of microbes or interfering with their metabolism are used in this process. Disinfection treatment is required to remove the pathogenic bacteria because the water produced from the phytoremediation process in this study does not fulfill the quality guidelines ( Eran Friedler et al.2011). Therefore, in this process a beaker sample experimentation of $1 \%, 2 \%, 3 \%$ sodium Hypochlorite was added to 1 liter of untreated greywater to 
check the disinfection reaction. These concentrations showed a substandard removal efficiencies of $\mathrm{E}$. coli and salmonella colonies. Finally, addition of Sodium Hypochlorite (4\%) W/V available chlorine was added which removed E. coli and salmonella completely, subsequently the treated greywater can be used for organic gardening and for other secondary uses.

\section{Conclusion}

A large quantity of recycled greywater in this study was found to be used as an alternative water source in households but the intake is very much based on the health and safety perception. This study evaluated the efficiency of a VFWC tank with phytoremediation and disinfection unit to reduce pollutants in greywater. The outcomes showed the organic pollutant removal efficiency was $56.56 \%$ and $50.25 \%$ for BOD5 and COD respectively, while the solids content TSS and TDS had an efficiency of $68 \%$ and $64.4 \%$ respectively. The salt cl- and $\mathrm{Na}+$ removal efficiencies were $63.4 \%$ and $81.39 \%$ by Typha angustifolia. The E. Coli and salmonella were satisfactorily removed using the disinfection unit. The results revealed that Typha angustifolia plant was more feasible in reducing the experimental water parameters. The capacity of 5 VFWC tanks holds approximately 390 liters of greywater. After the treatment process, on 90 th day the quantity of greywater collected was 350 liters, which was used for organic gardening and the remaining water was passed to the ground water table connected with the rain water harvesting pipes satisfying the objective of the project

\section{Declarations}

Ethics approval: Not applicable

Consent to participate: Not applicable

Consent for publication: Not applicable

Authors' contribution: Neetha Delphin Mary Kulandaiswamy identified the problem, conducted various tests and analyses and involved in preparation of manuscript. Muralimohan Nithyanandam is supervisor of first author, interpreted results and involved in preparation of manuscript. All authors read and approved the final manuscript.

Funding: The authors declare that no funds, grants, or other support were received during the preparation of this manuscript.

Competing interests: The authors declare no competing interests.

Availability of data and materials: The datasets used and/or analyzed during the current study are available from the corresponding author on reasonable request.

\section{References}


A. Abdel hay, S.G. Abunaser (2020) Modeling and Economic Analysis of Greywater Treatment in Rural Areas in Jordan Using a Novel Vertical-Flow Constructed Wetland. Environmental Management, pp.1-12, 2020.

S.N. Abed, S.A. Almuktar, M. Scholz (2019) Phytoremediation performance of floating treatment wetlands with pelletized mine water sludge for synthetic greywater treatment. Journal of Environmental Health Science and Engineering, vol.17, no.2, pp.581-608.

Adonadaga, M-G, Takramah, Bks; Ampadu, B; Sackey (2020) Performance Evaluation of Three Different Grasses for Use as Willows in Greywater Treatment in Semi-arid Ghana, J. Appl. Sci. Environ. Manage. Electronic ISSN 1119-8362, Vol. 24 (1) 179-185.

B. F. Bakare, S. Mtsweni, S. Rathilal (2017) Characteristics of greywater from different sources within households in a community in Durban, South Africa. Journal of water reuse and Desalination, Doi: 10.2166/wrd.2016.092.

P. Beauchamp, J. Adamowski (2012) Different methods to assess green infrastructure costs and benefits in housing development projects. Journal of Sustainable Development, vol.5, no.4, pp.1-21.

R.R. Canales-Pastrana, M. Paredes (2013) Phytoremediation dynamic model as an assessment tool in the environmental management. Open Journal of Applied Sciences, vol.3, pp.208-217.

B. L. Chavan, V. P. Dhulap (2012) Optimization of pollutant concentration in sewage treatment using constructed wetland through phytoremediation. International Journal of Advanced Research in Engineering and Applied Sciences. ISSN: 2278-6252.

M. Cristina Negri, DSA (Dottore in Scienze Agrarie), Ray R. Hinchman (1996) Plants That Remove Contaminants from the Environment. Downloaded from https://academic.oup.com/labmed/articleabstract/27/1/36/2503490

RI. E. crundwell (1986). Review of hydrophyte Evapotranspiration. Hydrobiol. Irop. 19 (3-4): 215-232

N. Dal Ferro, C. De Mattia, M.A. Gandini, C. Maucieri, P. Stevanato, A. Squartini, M. Borin (2020.) Green walls to treat kitchen greywater in urban areas: Performance from a pilot-scale experiment. Science of The Total Environment, vol.757, pp.144189.

S. Deng, B. Xie, Q. Kong, S. Peng, H. Wang, Z. Hu, D. Li (2020) An oxic/anoxic-integrated and Fe/C microelectrolysis-mediated vertical constructed wetland for decentralized low-carbon greywater treatment. Bioresource Technology, vol.315, pp.123802.

Eran Friedler;Anat Yardeni,Yael Gilboa,Yuval Alfiya (2011) Disinfection of greywater effluent and regrowth potential of selected bacteria.. Water Sci Technology 63 (5): 931940,https://doi.org/10.2166/wst.2011.272. 
Eric R. Rozema, Robert J. Gordon, Youbin Zheng (2014) Plant Species for the Removal of $\mathrm{Na}^{+}$and $\mathrm{Cl}^{-}$ from Greenhouse Nutrient Solution. Volume 49: Issue 8, https://doi.org/10.21273/HORTSCI.49.8.1071

L. Hernández Leal, H. Temmink, G. Zeeman, C.J. Buisman (2010) Comparison of three systems for biological greywater treatment. Water, vol.2, no.2, pp.155-169.

Jianjun Chen (2003) Role of phytoremediation in contaminated soil. University of Florida, DOI: 10.1201/9780203912317.ch17.

Z. Li, F. Boyle, A. Reynolds (2010) Rainwater harvesting and greywater treatment systems for domestic application in Ireland. Desalination, vol.260, no.1-3, pp.1-8.

S. Manzoni, A. Molini, A. Porporato (2011) Stochastic modelling of phytoremediation. Proceedings of the Royal Society A: Mathematical, Physical and Engineering Sciences, vol.467, no.2135, pp.3188-3205.

Michael L. Goulden, Marcy Litvak, Scott D. Miller (2007) Factors that control Typha marsh evapotranspiration. Aquatic Botany, doi: 10.1016/j.aquabot.2006.09.005.

Mohamed, A. Al-Gheethi, A. Abdulrahman, M.S. Bin Sainudin, S.A. Bakar, A.H.M. Kassim (2018). Optimization of ceramic waste filter for bathroom greywater treatment using central composite design (CCD). Journal of Environmental Chemical Engineering, vol.6, no.2, pp.1578-1588.

Mónica Eljaiek-Urzola, Nora Romero-Sierra, Laura Segrera-Cabarcas, David Valdelamar-Martínez, Édgar Quiñones-Bolaños (2019) Oil and Grease as a Water Quality Index Parameter for the Conservation of Marine Biota, Water, 11, 856; doi:10.3390/w11040856, www.mdpi.com/journal/water.

Morel A., Diener S (2006) Greywater Management in Low and Middle-Income Countries, Review of different treatment systems for households or neighborhoods. Swiss Federal Institute of Aquatic Science and Technology (Eawag). Dubendorf, Switzerland. ISBN:3906484-37-8;978-3-906484-37-2.

Munazzam Jawad Shahid, Ameena A. AL-surhanee Fayza Kouadri, Shafaqat Ali, Neeha Nawaz, Muhammad Afzal, Muhammad Rizwan, Basharat Ali, Mona H. Soliman (2020) Role of Microorganisms in the Remediation of Wastewater in Floating Treatment Wetlands: A Review. Sustainability, 12, 5559; doi:10.3390/su12145559, www.mdpi.com/journal/sustainability.

Nandhagopal Boopathi, Rajeshkumar Kadarkarai (2021) A Laboratory-Scale Study of Residential Greywater Treatment with Sugarcane in a Constructed Wetland, DOI: https://doi.org/10.21203/rs.3.rs630390/v1

Neharika Chandekar, Buddharatna J. Godboley (2015) A Review on Phytoremediation A Sustainable Solution for Treatment of Kitchen Wastewater. International Journal of Science and Research (IJSR). ISSN (Online): 2319-7064 Index Copernicus Value 78.96. 
Ni Nyoman Nepi Marleni, Ristie Ermawati, Nurul Alvia Istiqomah (2020) The Application of Combined Phytoremediation Greywater Treatment in A Single House. Journal of the Civil Engineering Forum, 7(1):47-58, DOI 10.22146/jcef.58218, https://jurnal.ugm.ac.id/jcef/issue/archive.

C. Noutsopoulos, A. Andreadakis, N. Kouris, D. Charchousi, P. Mendrinou, A. Galani, I. Mantziaras, E. Koumaki (2018) Greywater characterization and loadings-physicochemical treatment to promote onsite reuse. Journal of environmental management, vol.216, pp.337-346.

Nur Izzah Hamna Abdul Aziz, Marlia Mohd Hanafiah, Nasrun Hisyam Halim, Putri Amylin Sofea Fidril (2020) Phytoremediation of TSS, NH3-N and COD from Sewage Wastewater by Lemna minor L., Salvinia minima, Ipomea aquatica and Centella asiatica. Appl. Sci. 5397; doi:10.3390/app10165397.

Oren Shelef, Amit Gross and Shimon Rachmilevitch (2013) Role of Plants in a Constructed Wetland: Current and New Perspectives. Water 5, 405-419; doi:10.3390/w5020405, ISSN 2073-4441, www.mdpi.com/journal/water.

M. Oteng-Peprah, N. de Vries, M.A. Acheampong (2020) Households' willingness to adopt greywater treatment technologies in a developing country-Exploring a modified theory of planned behavior (TPB) model including personal norm. Journal of environmental management, vol.254, pp.109807.

S. Pradhan, M.I. Helal, S.G. Al-Ghamdi, H.R. Mackey (2020) Performance evaluation of various individual and mixed media for greywater treatment in vertical nature-based systems. Chemosphere, vol.245, pp.125564.

Rajnikant Prasad, Dayanand Sharma, Kunwar D Yadav, Hussameldin Ibrahim (2021) Preliminary study on greywater treatment using water hyacinth. Applied Water Science 11:88, https:doi.org/10.1007/s13201021-01422-4.

A. R. Raju, C. T. Anitha, P. D. Sidhimol, K. J. Rosna (2010) Phytoremediation of Domestic Wastewater by Using a Free-Floating Aquatic Angiosperm, Lemna minor. Nat. Env. Poll. Tech, ISSN: 0972-6268, www.neptjournal.com

D.O. Raphael, D.A. Okunade, K. Ogedengbe, O.A. Adekunle (2020) Assessment of a batch-flow free water surface constructed wetland planted with Rhynchospora corymbosa (L.) Britton for campus greywater treatment. Environmental Science and Pollution Research, vol.27, no.4, pp.4275-4283.

D.R. Samayamanthula, C. Sabarathinam, H. Bhandary (2019) Treatment and effective utilization of greywater. Applied Water Science, vol.9, no.90.

Sheena K.N, Harsha P (2016) Feasibility Study of Phytoremediation in Wastewater Treatment. International Journal of Science and Research (IJSR) ISSN (Online): 2319-7064 Index Copernicus Value: 79.57 . 
J.T. Spangler, D.J. Sample, L.J. Fox, J.S. Owen Jr, S.A. White (2019). Floating treatment wetland aided nutrient removal from agricultural runoff using two wetland species. Ecological Engineering, vol.127, pp.468-479.

\section{Graphs}

The graphs presented in the Results and Discussion are available in the Supplemental Files section

\section{Figures}

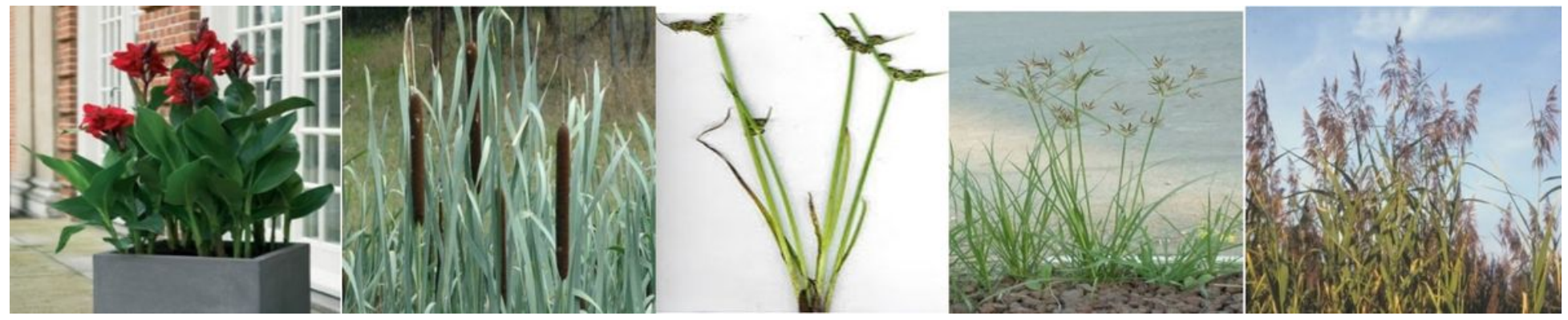

\section{Figure 1}

Photographic view of selected plants from left to right: Canna indica, Typha angustifolia, Cyperus pangorei, Cyperus rotundus and Phragmites australis

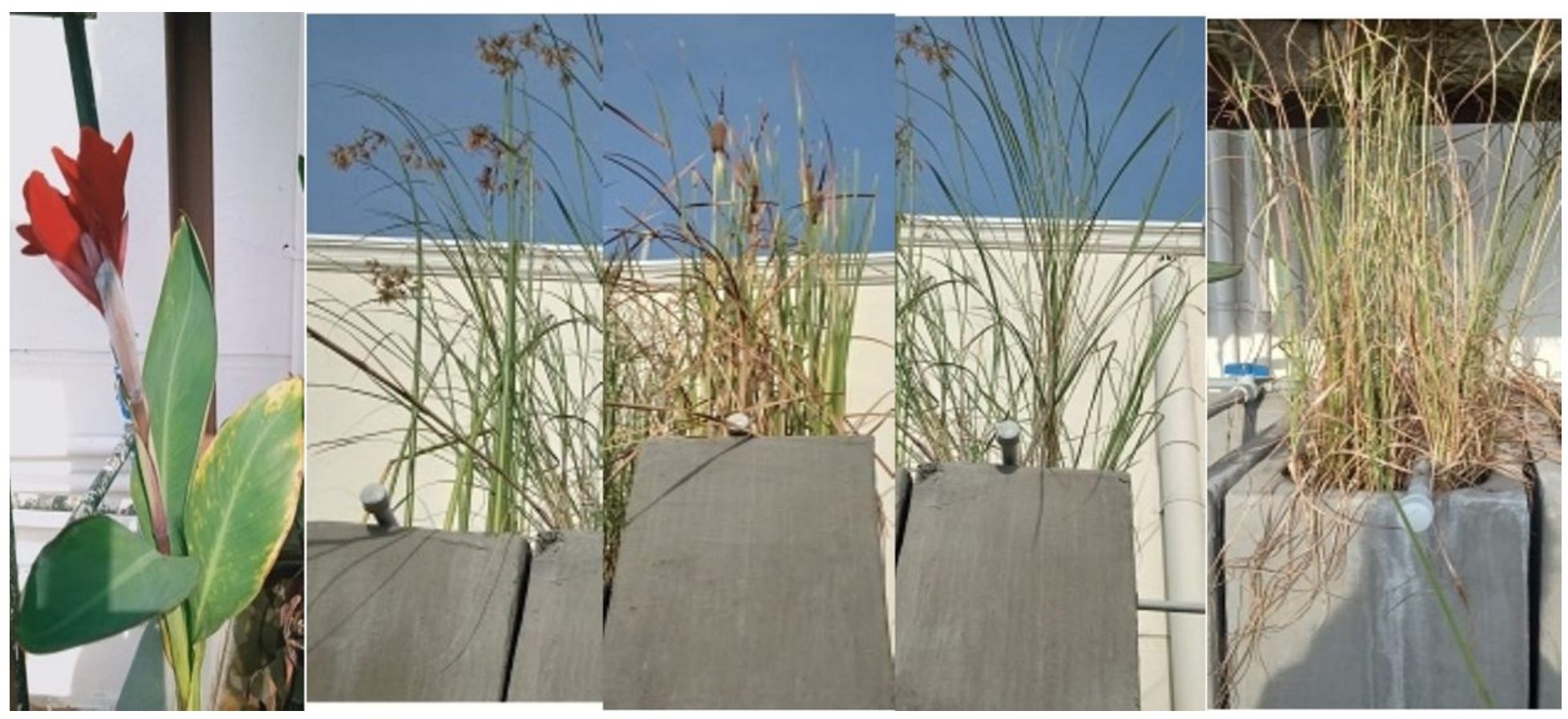

Figure 2

Photographic view of plant on the $90^{\text {th }}$ day from left to right: Canna indica, Cyperus pangorei, Typha angustifolia, Phragmites australis and Cyperus rotundus 


\section{Supplementary Files}

This is a list of supplementary files associated with this preprint. Click to download.

- drawingimage1.png

- drawingimage2.png

- drawingimage3.png

- drawingimage4.png

- drawingimage5.png

- drawingimage6.png

- drawingimage7.png

- drawingimage8.png 